\title{
ASTHMA-COPD OVERLAP: DIAGNOSTIC CRITERIA AND PREDICTORS OF OUTCOME
}

By

\section{Ahmed Ibrahem Mohamed Sheta, Moussa Antar Hussein, Esam Mohamed Ghamry and Ibrahim Metwally Bayoumi*}

\author{
Departments of Internal Medicine and Clinical Pathology*, Faculty of Medicine, Al-Azhar \\ University
}

Corresponding author: Ahmed Ibrahem Mohamed Sheta,

E-mail: drahmedsheta245@gmail.com

\begin{abstract}
Background: Distinguishing asthma from COPD can be problematic, particularly in smokers and old adults. Some patients may have clinical features of both asthma and COPD. Descriptive term asthma-COPD overlap (ACO) may be useful to maintain awareness by clinicians, researchers and regulators of the needs of these patients, since most guidelines and clinical trials are about asthma alone or COPD alone.
\end{abstract}

Objective: To guide better recognition of wide range criteria to identify asthma-COPD overlap and to encourage the development of specific interventions for clinical use.

Patients and methods: Our study was carried out on 85 Egyptian individuals, 10 healthy volunteers, 25 patients diagnosed as bronchial asthma, 25 patients diagnosed as COPD, and 25 patient diagnosed as asthmaCOPD overlap in clinical and investigation base ground, collected from Aga General Hospital, between June 2019 and February 2020.

Results: Our results demonstrated that 300 cells $/ \mu \mathrm{L}$ was the best cutoff value for blood esinophil counts in differentiating ACO from COPD. The sensitivity and specificity were $64 \%$ and $79 \%$, respectively. At a cutoff value of 8.47 sputum esinophil percentage sensitivity and specificity were $72.3 \%$ and $52.4 \%$, respectively. Also FeNO can be used to discriminate between ACO patients and COPD patients at a cutoff level of $>18.5$, with $52 \%$ sensitivity and $88 \%$ specificity. Also, there was a significant difference between the four studied groups regarding HDL and pulmonary function tests. So, blood and sputum esinophil count, FeNO, HDL, FEV1 and FEV1/FVC can be used as significant predictors for ACO.

Conclusion: The inflammatory biomarkers FeNO, sputum esinophils and blood esinophils can support the diagnosis of ACO, which may help clinicians to choose individualized treatment plan.

Keywords: Asthma-COPD, ACO, FEV1/FVC, FeNO.

\section{INTRODUCTION}

Asthma-COPD overlap (ACO) is characterized by persistent airflow limitation and several manifestations usually associated with both asthma and COPD. There is broad agreement that patients with ACO have worse outcomes than patients with COPD or asthma alone, unless they receive adequate treatment, which includes inhaled corticosteroids (ICS) (Global Initiative for Asthma, 2019).

Han et al. (2010) first proposed the concept of COPD phenotype, according to the symptoms, acute exacerbation, effectiveness of treatment, degree of 
progression, and death related to the same characteristics of patients with COPD. Soler et al. (2012) proposed phenotypic diagnosis, and ACO was distinguished as an independent phenotype.

According to epidemiological survey, ACO accounts for $10 \%$ to $20 \%$ of COPD. In 50 to 59- year-old patients, the prevalence rate is about $23 \%$, and in 70 to 79 year old patients this rate increases to $52 \%$ with over $50 \%$ of all obstructive lung disease occurring in elderly patients. These patients have frequent acute exacerbations of respiratory symptoms, a poorer quality of life, and increased mortality rate (Mostafavi et al., 2018).

Although the Global Initiative for Asthma (GINA) and the Global initiative for chronic Obstructive Lung Disease (Global Initiative for Chronic Obstructive Lung Disease, 2019) proposed a stepwise approach for the diagnosis of ACO, the diagnostic criteria were based on syndromic features and lacked objective indicators, such as results from lung function testing, imaging, and testing for inflammatory biomarkers. Both fractional exhaled nitric oxide (FeNO) and blood eosinophils are used as inflammatory biomarkers for differentiating ACO from COPD.

Fractional exhaled nitric oxide (FeNO) as a hot spot in airway inflammation research, has advantages of more noninvasive, simple, fast, repeatability compared with traditional induced sputum examination. Also, elevated sputum eosinophils could be used as main criteria for ACO diagnosis (Guo et al., 2018).

Karampitsakos and Gourgoulianis (2016) believed that FeNO can help identify asthma and ACO phenotype.
Although Kobayashi et al. (2016) have reported that FeNO and blood eosinophil levels were good parameters for differentiating between ACO and COPD, several limitations were identified. First, ACO was not defined according to the universally accepted definition. Second, patients receiving ICS affect FeNO levels and blood eosinophil counts.

This study was aiming to guide better recognition of wide range criteria to identify asthma-COPD overlap, and to encourage the development of specific interventions for clinical use.

\section{PATIENTS AND METHODS}

This study was carried out on 85 Egyptian individuals. Their ages ranged from 26-66 years with mean age 47.2 \pm 9.5 years, 49 males and 36 females, all of them are collected from Aga General Hospital, between June 2019 and February 2020.

The studied individuals were classified into four groups:

Group 1 (control group): included 10 apparently healthy individuals.

Group 2 included 25 individuals having bronchial asthma.

Group 3 included 25 individuals having COPD.

Group 4 included 25 individuals having asthma-COPD overlap.

\section{Inclusion criteria:}

Patients included in this study were those aged 18 years or more and diagnosed as COPD or bronchial asthma (BA) or asthma-COPD overlap and 10 healthy volunteers according to Global Initiative for Asthma (2019) guide lines. 


\section{Exclusion criteria:}

Patients with acute exacerbation, patients receiving systemic steroid in last 4 weeks, patients have organ failure as congestive heart failure, liver cell failure, patients with systemic inflammatory disorder, pregnant female, patient with recent infection, patients with other lung disease as interstitial lung fibrosis, patients with allergic diseases as urticaria and allergic rhinitis.

\section{All individuals were subjected to the following:}

- Full history taking.

- General examination with special attention to signs of allergic rhinitis, nasal polyps, allergic conjunctivitis, and atopic dermatitis.

- Local examination of the chest.

- Plain chest X-ray (Postero-Anterior view) to exclude other chest diseases as pneumonia and pneumothorax.

- Liver functions, kidney functions, random blood sugar and BMI.

- CBC with special emphasize on eosinophil count.

- Sputum eosinophil count.

- Fasting HDL, LDL, Triglycerides.

- Fractional exhaled Nitric Oxide (FeNO).

- Pulmonary function test pre and post short acting bronchodilator by spirometer.

\section{Pulmonary function test preparation:}

- Spirometer was calibrated on a regular basis before every patient.
- Spirometers have a digital display of the expiratory curve to permit detection of technical errors.

- Maximal patient effort in performing the test was required to avoid underestimation of values and hence errors in diagnosis and management (Global Initiative for Chronic Obstructive Lung Disease, 2019).

- Taking confirmation from all patients that they didn't have any bronchodilators before test.

\section{Technique of pulmonary function test:}

All the tests were done with the patients sitting putting nose clips on his nose and fitting the lips on the mouth piece of apparatus with his teeth on it from inside, the patient was instructed to inhale maximally to total lung capacity and exhale, maximal and slowly to residual volume to measure the slow vital capacity (SVC), and to exhale forcedly and rapidly to measure the forced expiratory volume in the 1 st second (FEV1) and other inspiratory and expiratory parameters.

All tests were done for 3 times and the best measurement is selected and the FVC and FEV1 values in these three curves should vary by no more than $5 \%$ or 100 $\mathrm{ml}$, whichever is greater. The FEV1/FVC was taken from the technically acceptable curve with the largest sum of FVC and FEV1. Spirometry measurements are evaluated by comparison of the results with appropriate reference values based on age, height, sex, and race (Ghobain et al., 2013). The presence of a post bronchodilator FEV1/FVC $<0.70$ confirms the presence of airflow limitation. 
All the previous tests were done after 15 minutes of receiving $400 \mu \mathrm{g}$ of Salbutamol by inhalation and reversibility was estimated as regard (FEV1) after change.

\section{Measurement of exhaled Nitric Oxide (FeNO):}

FeNO was measured according to the American Thoracic Society/European Respiratory Society (ATS /ERS) guidelines using a hand-held device NO breath device.

The detection principle of NO for this device based on the electrochemical sensor technology. Any gas that can electrochemically oxidize or reduced can also be detected by means of an electrochemical sensor (Pisi et al., 2010).

To perform the test, patients were seated in the upright position without anose clip. Patients were then asked to inhale as deeply as possible and after 3 seconds guided by an auditory cue, to exhale through the mouthpiece, keeping the ball in the flow indicator in the middle of the black band in the center of the tube, at a constant flow rate of $50 \mathrm{ml} /$ second. The required exhalation time is approximately $12 \mathrm{~s}$. (Harnan et al., 2015).

To ensure a breath sample was taken at the correct flow rate, the monitor was held up right at all times during the test. Measurements were repeated after a brief rest period until tow acceptable values (+2.5 part per billion (ppb) for measurements $<50 \mathrm{ppb}$ and $+-5 \mathrm{ppb}$ for measurements $>50 \mathrm{ppb}$ ) were performed (maximum six attempts). The mean of two adequate values for each patient was recorded for analysis.
Interpretation of FeNO levels was done according to American Thoracic Society guidelines as follows:

- FeNO <25 ppb: Low (normal); eosinophilic inflammation and responsiveness to corticosteroids are less likely.

- FeNO 25-50 ppb: Intermediate; interpretation depends on whether the symptomatic patient presents for an initial diagnosis or is being treated and monitored over time.

- FeNO >50 ppb: High; eosinophilic inflammation and response to corticosteroid are likely.

\section{Specimen collection and transport:}

Sputum samples were taken after washing the mouth and before eating or drinking to not dilute saliva and decreasing bacteria. Patients were instructed to take deep breath, hold it for a moment and then cough vigorously into the $100 \mathrm{ml}$ sterile universal containers. Specimens were transported to microbiological laboratory within 2 hours.

Blood samples were collected to $\mathrm{CBC}$, RBS, HDL, LDL, TG.

\section{Statistical analysis:}

Recorded data were analyzed using the statistical package for the social sciences, version 20.0 (SPSS Inc., Chicago, Illinois, USA). Quantitative data were expressed as mean \pm standard deviation (SD). Qualitative data were expressed as frequency and percentage. Independentsamples t-test of significance was used when comparing between two means. Chisquare $\left(\mathrm{x}^{2}\right)$ test of significance was used in order to compare proportions between two qualitative parameters. The confidence 
interval was set to $95 \%$ and the margin of error accepted was set to $5 \%$. The p-value was considered significant when P-value
<0.05. Also ANOVA and post hoc tests were used.

\section{RESULTS}

Statistically significant difference (pvalue $=0.019$ ) was between control group and BA group as regard blood esinophil. No statistical significant difference (pvalue $=0.426$ ) was between control group and COPD group as regard blood esinophil. Statistically significant difference ( $\mathrm{p}$-value $=0.021$ ) was between control group and ACO group as regard blood esinophil. Statistically significant difference $(\mathrm{p}$-value $=0.038)$ was between BA group and COPD group as regard blood esinophil. No statistical significant difference $(p$-value $=0.952$ ) was between BA group and ACO group as regard blood esinophil. Statistically significant difference ( $\mathrm{p}$-value $=0.043$ ) was between COPD group and ACO group as regard blood esinophil (Table 1).

Table (1): Comparisons between studied groups as regard blood esinophil

\begin{tabular}{|c|c|c|c|}
\hline \multirow{2}{*}{ Groups } & Parameters & LSD & p-value \\
\hline \multirow{3}{*}{ Control } & BA & $-\mathbf{1 3 5 . 5}$ & $\mathbf{0 . 0 1 9}$ \\
\cline { 2 - 4 } & COPD & -45.2 & 0.426 \\
\cline { 2 - 4 } & ACO & $-\mathbf{1 3 2 . 9}$ & $\mathbf{0 . 0 2 1}$ \\
\hline \multirow{2}{*}{ BA } & COPD & $\mathbf{9 0 . 3}$ & $\mathbf{0 . 0 3 8}$ \\
\cline { 2 - 4 } & ACO & 2.6 & 0.952 \\
\hline COPD & ACO & $\mathbf{- 8 7 . 7}$ & $\mathbf{0 . 0 4 3}$ \\
\hline
\end{tabular}

There was a statistically significant difference $(\mathrm{p}$-value $=0.001)$ between control group and BA group as regard sputum esinophil. No statistical significant difference $(\mathrm{p}$-value $=0.342)$ between Control group and COPD group as regard sputum esinophil. Statistical significant differences ( $\mathrm{p}$-value $<0.001$ ) were between control group and ACO group as regard sputum esinophil. Statistically significant difference $(\mathrm{p}$-value $=0.002)$ were between BA group and COPD group as regard sputum esinophil. No statistical significant difference $(p$-value $=0.664)$ were between BA group and ACO group as regard sputum esinophil. Statistical significant differences ( $\mathrm{p}$-value $<0.001$ ) were between COPD group and ACO group as regard sputum esinophil (Table 2).

Table (2): Comparisons between studied groups as regard sputum esinophil

\begin{tabular}{|c|c|c|c|}
\hline \multirow{2}{*}{ Groups } & Parameters & LSD & p-value \\
\hline \multirow{3}{*}{ Control } & BA & $\mathbf{- 4 . 2}$ & $\mathbf{0 . 0 0 1}$ \\
\cline { 2 - 4 } & COPD & -1.2 & 0.342 \\
\cline { 2 - 4 } & ACO & $\mathbf{- 4 . 6}$ & $<\mathbf{0 . 0 0 1}$ \\
\hline \multirow{2}{*}{ BA } & COPD & $\mathbf{3 . 1}$ & $\mathbf{0 . 0 0 2}$ \\
\cline { 2 - 4 } & ACO & -0.4 & 0.664 \\
\hline COPD & ACO & $\mathbf{- 3 . 4}$ & $<\mathbf{0 . 0 0 1}$ \\
\hline
\end{tabular}


There was a significant difference between the four studied groups regarding FeNO (Table 3).

Table (3): FENO levels of the studied groups

\begin{tabular}{|c|c|c|c|c|c|}
\hline $\begin{array}{c}\text { Groups } \\
\text { FeNO }\end{array}$ & $\begin{array}{c}\text { Controls } \\
(\mathbf{N}=\mathbf{1 0})\end{array}$ & $\begin{array}{c}\mathbf{B A} \\
(\mathbf{N}=\mathbf{2 5})\end{array}$ & $\begin{array}{c}\text { COPD } \\
(\mathbf{N}=\mathbf{2 5})\end{array}$ & $\begin{array}{c}\text { ACO } \\
(\mathbf{N}=\mathbf{2 5})\end{array}$ & $\mathbf{P}$ \\
\hline Mean \pm SD & $18.9 \pm 15.9$ & $42.4 \pm 32.7$ & $15.3 \pm 24.6$ & $46.9 \pm 35.1$ & $\mathbf{0 . 0 0 1}$ \\
\hline
\end{tabular}

Statistically significant difference ( $p$ value $=0.038$ ) was between control group and BA group as regard FENO. No statistical significant difference $(\mathrm{p}$-value $=$ 0.749 ) was between control group and COPD group as regard FENO. Statistically significant difference ( $\mathrm{p}$-value $=0.014)$ was between control group and ACO group as regard FENO. Statistically significant difference ( $\mathrm{p}$-value $=0.002$ ) was between BA group and COPD group as regard FENO. No statistical significant difference $(\mathrm{p}$-value $=0.6)$ was between BA group and ACO group as regard FENO. Statistical significant difference (p-value < 0.001) was between COPD group and ACO group as regard FENO (Table 4).

Table (4): Comparisons between studied groups as regard FENO

\begin{tabular}{|c|c|c|c|}
\hline \multirow{2}{*}{ Groups } & Parameters & LSD & p-value \\
\hline \multirow{3}{*}{ Control } & BA & $\mathbf{- 2 3 . 5}$ & $\mathbf{0 . 0 3 8}$ \\
\cline { 2 - 4 } & COPD & 3.58 & 0.749 \\
\cline { 2 - 4 } & ACO & $\mathbf{- 2 7 . 9}$ & $\mathbf{0 . 0 1 4}$ \\
\hline BA & COPD & $\mathbf{2 7 . 1}$ & $\mathbf{0 . 0 0 2}$ \\
\hline & ACO & -4.44 & 0.6 \\
\hline COPD & ACO & $\mathbf{- 3 1 . 5}$ & $<\mathbf{0 . 0 0 1}$ \\
\hline
\end{tabular}

There was a highly significant difference between the four studied groups regarding FEV1, FVC and
FEV/FVC before bronchodilator (Table 5).

Table (5): Pulmonary function tests of the studied groups before bronchodilator

\begin{tabular}{|c|c|c|c|c|c|}
\hline $\begin{array}{c}\text { Groups } \\
\text { Parameters }\end{array}$ & $\begin{array}{c}\text { Controls } \\
(\mathbf{N = 1 0 )}\end{array}$ & $\begin{array}{c}\text { BA } \\
(\mathbf{N = 2 5})\end{array}$ & $\begin{array}{c}\text { COPD } \\
\mathbf{( N = 2 5 )}\end{array}$ & $\begin{array}{c}\text { ACO } \\
(\mathbf{N = 2 5})\end{array}$ & P \\
\hline $\begin{array}{c}\text { FEV }_{1}(\%) \\
\text { Mean } \pm \text { SD }\end{array}$ & $92.88 \pm 4.62$ & $80.83 \pm 12.03$ & $56.7 \pm 4.77$ & $55.1 \pm 1.9$ & $<\mathbf{0 . 0 0 1}$ \\
\hline $\begin{array}{c}\text { FVC (\%) } \\
\text { Mean } \pm \text { SD }\end{array}$ & $95.54 \pm 5.07$ & $84.62 \pm 9.89$ & $77.6 \pm 7.63$ & $75.1 \pm 4.51$ & $<\mathbf{0 . 0 0 1}$ \\
\hline $\begin{array}{c}\text { FEV/FVC } \\
\text { Mean } \pm \text { SD }\end{array}$ & $94.24 \pm 3.84$ & $73.12 \pm 6.44$ & $51.6 \pm 9.51$ & $51.2 \pm 8.1$ & $<\mathbf{0 . 0 0 1}$ \\
\hline
\end{tabular}

There was a highly significant difference between the four studied groups regarding FEV1, FVC and FEV/FVC after bronchodilator (Table 6). 
Table (6): Pulmonary function tests of the four studied groups after bronchodilator

\begin{tabular}{|c|c|c|c|c|c|}
\hline Groups & $\begin{array}{c}\text { Controls } \\
(\mathbf{N = 1 0})\end{array}$ & $\begin{array}{c}\text { BA } \\
(\mathbf{N = 2 5})\end{array}$ & $\begin{array}{c}\text { COPD } \\
(\mathbf{N = 2 5})\end{array}$ & $\begin{array}{c}\text { ACO } \\
(\mathbf{N = 2 5})\end{array}$ & P \\
\hline $\begin{array}{c}\text { Parameters } \\
\text { Mean }(\%)\end{array}$ & $93.9 \pm 7.6$ & $91.21 \pm 9.33$ & $61.87 \pm 13.62$ & $69.3 \pm 14.5$ & $<\mathbf{0 . 0 0 1}$ \\
\hline $\begin{array}{c}\text { FVC }(\%) \\
\text { Mean } \pm \text { SD }\end{array}$ & $96.9 \pm 28.5$ & $\begin{array}{c}90.79 \pm \\
17.21\end{array}$ & $84.74 \pm 11.35$ & $\begin{array}{c}87.62 \pm \\
15.2\end{array}$ & $<\mathbf{0 . 0 0 1}$ \\
\hline $\begin{array}{c}\text { FEV/FVC } \\
\text { Mean } \pm \text { SD }\end{array}$ & $94.7 \pm 8.2$ & $\begin{array}{c}84.11 \pm \\
11.75\end{array}$ & $56.63 \pm 12.6$ & $\begin{array}{c}59.19 \pm \\
10.8\end{array}$ & $<\mathbf{0 . 0 0 1}$ \\
\hline
\end{tabular}

There was no statistical significant variability response between pre and postcontrols with p-value $0.48,0.5$ and 0.87 BD FEV1, FVC and FEV1/FVC in respectively (Table 7).

Table (7): Pulmonary function tests before and after bronchodilator in controls

\begin{tabular}{|c|c|c|c|}
\hline Controls & $\begin{array}{c}\text { Before } \\
(\mathbf{N}=10)\end{array}$ & $\begin{array}{c}\text { After } \\
(\mathbf{N = 1 0})\end{array}$ & p-value \\
\hline $\begin{array}{c}\text { FEV } 1 \text { (\%) } \\
\text { Mean } \pm \text { SD }\end{array}$ & $92.88 \pm 4.62$ & $93.9 \pm 7.6$ & 0.48 \\
\hline $\begin{array}{c}\text { FVC (\%) } \\
\text { Mean } \pm \text { SD }\end{array}$ & $95.54 \pm 5.07$ & $96.9 \pm 28.5$ & 0.5 \\
\hline $\begin{array}{c}\text { FEV/FVC } \\
\text { Mean } \pm \text { SD }\end{array}$ & $94.24 \pm 3.84$ & $94.7 \pm 8.2$ & 0.87 \\
\hline
\end{tabular}

There was a highly statistical significant variability response between pre and post-BD FEV1, FEV1/FVC and statistical significant variability according to FVC in BA patients with p-value < 0.001 and 0.0126 respectively (Table 8).

Table (8): Pulmonary function tests before and after bronchodilator in BA

\begin{tabular}{|c|c|c|c|}
\hline BA & $\begin{array}{c}\text { Before } \\
\text { Parameters }\end{array}$ & $\begin{array}{c}\text { After } \\
(\mathbf{N}=\mathbf{2 5})\end{array}$ & p-value \\
\hline $\begin{array}{c}\text { FEV }(\%) \\
\text { Mean } \pm \text { SD }\end{array}$ & $80.83 \pm 12.03$ & $91.21 \pm 9.33$ & $<\mathbf{0 . 0 0 1}$ \\
\hline $\begin{array}{c}\text { FVC (\%) } \\
\text { Mean } \pm \text { SD }\end{array}$ & $84.62 \pm 9.89$ & $90.79 \pm 17.21$ & 0.012 \\
\hline $\begin{array}{c}\text { FEV/FVC } \\
\text { Mean } \pm \text { SD }\end{array}$ & $73.12 \pm 6.44$ & $84.11 \pm 11.75$ & $<\mathbf{0 . 0 0 1}$ \\
\hline
\end{tabular}

There was no statistical significant variability response between pre and postBD FEV1, FVC and FEV1/FVC in COPD patients with p-value $0.17,0.06$ and 0.76 respectively (Table 9). 
Table (9): Pulmonary function tests before and after bronchodilator in COPD

\begin{tabular}{|c|c|c|c|}
\hline COPD & $\begin{array}{c}\text { Before } \\
(\mathbf{N = 2 5})\end{array}$ & $\begin{array}{c}\text { After } \\
(\mathbf{N = 2 5})\end{array}$ & p-value \\
\hline $\begin{array}{c}\text { PEV } 1 \text { (\%) } \\
\text { Mean } \pm \text { SD }\end{array}$ & $55.7 \pm 1.9$ & $61.87 \pm 13.62$ & $\mathbf{0 . 1 7}$ \\
\hline $\begin{array}{c}\text { FVC (\%) } \\
\text { Mean } \pm \text { SD }\end{array}$ & $77.6 \pm 4.51$ & $84.74 \pm 11.35$ & $\mathbf{0 . 0 6}$ \\
\hline $\begin{array}{c}\text { FEV/FVC } \\
\text { Mean } \pm \text { SD }\end{array}$ & $51.6 \pm 8.1$ & $56.63 \pm 12.6$ & 0.076 \\
\hline
\end{tabular}

There was a highly statistical significant variability response between pre and post-BD FEV1 and Statistical pre and post-BD FVC and FEV1/FVC in ACO patients with p-value $<0.001,0.003$ and 0.01 respectively (Table 10).

significant variability response between

Table (10): Pulmonary function tests before $\&$ after bronchodilator in ACO

\begin{tabular}{|c|c|c|c|}
\hline ACO & $\begin{array}{c}\text { Before } \\
(\mathbf{N = 2 5})\end{array}$ & $\begin{array}{c}\text { After } \\
(\mathbf{N = 2 5})\end{array}$ & p-value \\
\hline $\begin{array}{c}\text { FEV } 1 \text { (\%) } \\
\text { Mean } \pm \text { SD }\end{array}$ & $55.1 \pm 4.77$ & $69.3 \pm 14.5$ & $<\mathbf{0 . 0 0 1}$ \\
\hline $\begin{array}{c}\text { FVC (\%) } \\
\text { Mean } \pm \text { SD }\end{array}$ & $75.1 \pm 7.63$ & $87.62 \pm 15.2$ & 0.003 \\
\hline $\begin{array}{c}\text { FEV/FVC } \\
\text { Mean } \pm \text { SD }\end{array}$ & $51.2 \pm 9.51$ & $59.19 \pm 10.8$ & 0.01 \\
\hline
\end{tabular}

Using ROC curve (Fig. 1 \& 2):

FeNO discriminated between ACO patients and COPD patients at a cutoff level of $>18.5$, with $52 \%$ sensitivity, $88 \%$ specificity $(\mathrm{AUC}=0.62)$. Blood esinophil can be used to discriminate between ACO patients and COPD patients at a cutoff level of > 300, with $64 \%$ sensitivity, $79 \%$ specificity (AUC = 0.928). Sputum esinophil discriminated between ACO patients and COPD patients at a cutoff level of $>18.5$, with $72.3 \%$ sensitivity, $52.4 \%$ specificit. (AUC $=0.62$ ) (Tables 11 and 12). 


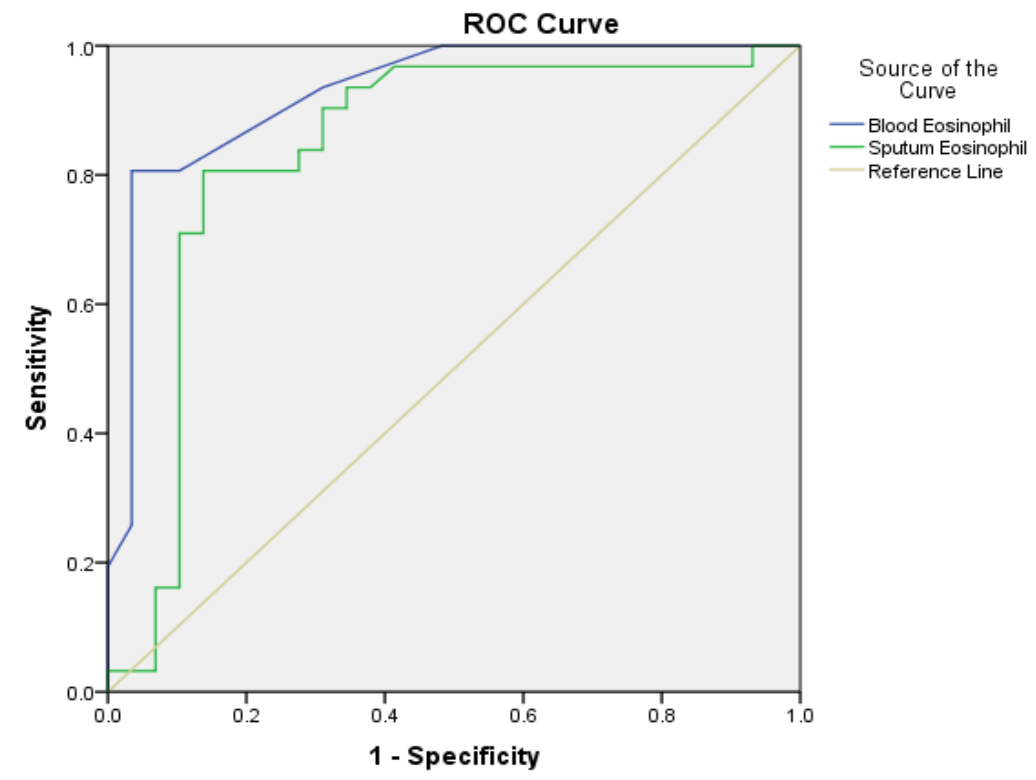

Figure (1): ROC curve between patients with ACO and COPD as regard Blood esinophil and Sputum esinophil

Table (11): Diagnostic performance of esinophils in discrimination of ACO from COPD

\begin{tabular}{|c|c|c|c|c|c|c|c|}
\hline Analysis & AUC & S.E & Sig. & Sensitivity & Specificity & \multicolumn{2}{|c|}{$\begin{array}{c}95 \% \\
\text { Confidence } \\
\text { Interval }\end{array}$} \\
\hline $\begin{array}{c}\text { Variables } \\
\begin{array}{c}\text { Blood Esinophil } \\
(>\mathbf{3 0 0})\end{array}\end{array}$ & .928 & .034 & .000 & $64 \%$ & $79 \%$ & .861 & .995 \\
\hline $\begin{array}{c}\text { Sputum Esinophil } \\
(>\mathbf{8 . 3 7})\end{array}$ & .838 & .059 & .000 & $72.3 \%$ & $52.4 \%$ & .723 & .953 \\
\hline
\end{tabular}

ACO vs COPD

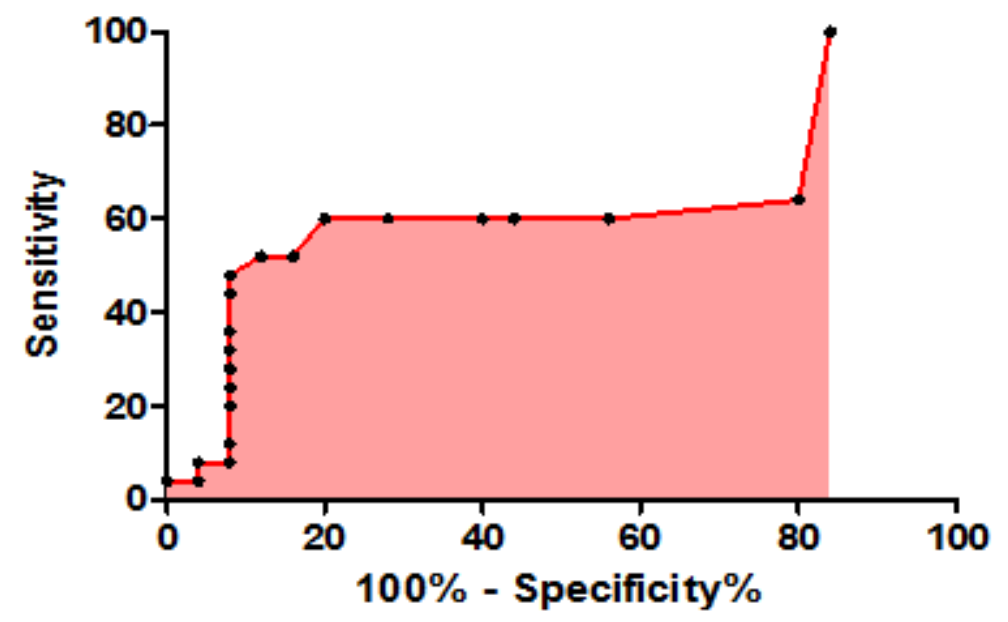

Figure (2): ROC curve between patients with ACO and COPD as regard FeNO 
Table (12): Diagnostic performance of FeNO in discrimination of ACO from COPD

\begin{tabular}{|c|c|c|c|c|c|c|}
\hline Analysis & AUC & Sensitivity & Specificity & PPV & NPV & $\begin{array}{c}\text { p- } \\
\text { value }\end{array}$ \\
\hline $\begin{array}{c}\text { ACO vs COPD } \\
(>18.5)\end{array}$ & 0.62 & $52 \%$ & $88 \%$ & $81.3 \%$ & $64.7 \%$ & $\mathbf{0 . 1 2 7}$ \\
\hline
\end{tabular}

PPV: positive predictive value. AUC: Area under curve NPV: negative predictive value.

Blood and sputum esinophil count, FeNO, FEV1, FVC and FEV1/FVC were significant predictors (Table 13).

Table (13): Multivariable logistic regression analysis, to detect the possible predictors the overlap

\begin{tabular}{|c|c|c|c|c|c|}
\hline Analysis & \multirow{2}{*}{ OR } & \multirow{2}{*}{ S.E. } & \multirow{2}{*}{ Sig. } & \multicolumn{2}{|c|}{ 95\% C.I. for OR } \\
\cline { 5 - 6 } Parameters & 1.508 & 0.071 & $\mathbf{0 . 0 0 7}$ & 1.153 & 2.671 \\
\hline Bl. esinophil & & & Lower & Upper \\
\hline S. esinophil & 1.642 & 0.049 & $\mathbf{0 . 0 0 4}$ & 1.036 & 2.784 \\
\hline FeNO & 2.313 & 0.058 & $\mathbf{0 . 0 0 1}$ & 1.064 & 3.104 \\
\hline FEV $_{1}$ & 1.548 & 0.065 & $\mathbf{0 . 0 1 9}$ & 1.065 & 2.431 \\
\hline FVC & 1.264 & 0.047 & 0.043 & 0.978 & 1.846 \\
\hline FEV $_{1} /$ FVC & 2.084 & 0.032 & $\mathbf{0 . 0 0 2}$ & 1.715 & 4.611 \\
\hline
\end{tabular}

\section{DISCUSSION}

Our understanding of asthma-COPD overlap is at a very preliminary stage. This study was aiming to guide better recognition of wide range criteria to identify asthma-COPD overlap and to encourage the development of specific interventions for clinical use.

Our study regarding FENO showed that its level was significantly higher in BA group and ACO group than control group. It was higher in BA group than COPD group. Also, it was highly significant higher in ACO group than COPD group. There was no statistical significant difference between both control group and COPD group and between BA group and ACO group.

Our findings were in agreement with that of Takayama et al. (2018) who found that the FeNO levels were higher in patients with ACO than in patients with COPD among patients naive to ICS.
Mostafavi et al. (2018) investigated the role of FENO measurement to differentiate COPD from ACO and revealed that FENO level is higher in ACO patients than COPD-only. Also, Bilun et al. (2014) found Increasing in FENO level in 416 asthmatics compared to controls.

Regarding blood esinophils, we found that it was significant higher in both BA group and ACO group than control group. Also, its level in both ACO group and BA group was significantly higher than COPD group. There was no statistical significant difference between both control group and COPD group and between BA group and ACO group.

Our findings came in agreement with Takayama et al. (2018) who have found that the blood esinophil counts were higher in patients with ACO than in patients with COPD. Also, Kobayashi et al. (2016) revealed that mean blood 
esinophil count and percentage are significantly higher in patients with ACO than in those without ACO.

As regard sputum esinophils, results of our study showed statistically significant difference between BA group and both Control group, COPD group. Also there was a statistically significant difference between ACO group and both Control group and COPD group. There was no statistical significant difference between both control group and COPD group and between BA group and ACO group.

Our study was in agreement with that of Guo et al. (2018) who completed the induced sputum examination in patients with ACO and patients with Non-ACO. The percentage of sputum esinophils in patients with ACO were over five times higher than those of patients with NonACO.

As regarding pulmonary function tests FEV1, FVC and FEV1/FVC before bronchodilator our study found that there was a highly statistical significant difference between control group and each of BA group, COPD group and ACO group. Also between BA group and both of COPD group and ACO group respectively. There was no statistical significant difference between COPD group and ACO group.

As regarding comparison FEV1, FVC and FEV1/FVC variability response pre and post bronchodilator, we found statistical significant difference according to variability of FEV1 in BA group and ACO group, but there was no statistical significant in COPD group. FVC variability has a statistical significant difference in BA group and ACO group.
FEV1/FVC variability response was a significant in BA group and ACO but it was not significant in COPD group.

Hye et al. (2018) found baseline FEV1 was similar between non-ACO COPD and ACO but post-bronchodilator FEV1 was higher for ACO than non-ACO COPD. Bethany et al. (2019) found there was no significant difference in variability in post-BD FEV1 and FVC in COPD patients.

Multivariable logistic regression analysis of our results revealed that blood and sputum esinophil count, FeNO, HDL, FEV1, FVC and FEV1/FVC were significant predictors for ACO.

Our ROC curve analysis showed that 300 cells $/ \mu \mathrm{L}$ was the best cutoff value for blood eosinophil counts in differentiating ACO from COPD. ROC curve analysis also showed that FeNO can be used to discriminate between ACO patients and COPD patients.

This was in agreement with Kitaguchi et al. (2012) who revealed $82.4 \%$ sensitivity and $84.8 \%$ specificity of sputum esinophil count for detecting COPD with asthma. Also, Kobayashi et al. (2016) demonstrated that the inflammatory biomarker FeNO supported the diagnosis of ACO. FeNO level showed $59.5 \%$ sensitivity and $85.5 \%$ specificity for the diagnosis of ACO. Also, Cheng et al. (2016) reported that the best diagnostic cutoff level of FeNO was $22.5 \mathrm{ppb}$, with $70.2 \%$ sensitivity and $75.0 \%$ specificity for differentiating ACO from COPD. Also, Takayama et al. (2018) demonstrated that 250 cells $/ \mu \mathrm{L}$ was the best cutoff value for blood esinophil counts in differentiating ACO from COPD. 


\section{CONCLUSION}

The inflammatory biomarkers FeNO, sputum esinophils and blood esinophils can support the diagnosis of ACO, which may help clinicians to choose individualized treatment plan. ACO was defined according to the universally accepted criteria in the joint GINA/GOLD document.

\section{REFERENCES}

1. Bethany $\mathrm{C}$, James $\mathbf{S}$ and Brendan $\mathrm{C}$. (2019): Within session variability of FEV1 and FVC pre- and post-bronchodilation. Eur Res Journal., 54: 1134.

2. Bilun G, Benan M and Ismail D. (2014): Fractional exhaled nitric oxide ( $\mathrm{FeNo})$ in different asthma phenotypes. Allergy Rhinol., 5: 157-161.

3. Cheng $S$ and Lin C. (2016): Effectiveness using higher inhaled corticosteroid dosage in patients with COPD by different blood esinophilic counts. Int $\mathbf{J}$ Chron Obstruct Pulmon Dis., 11: 2341-2348.

4. Ghobain M, Esam H, Hassan S and AlHajjaj S (2013): Spirometric reference values for healthy nonsmoking adults. Clin Resp J., 8: 157-163.

5. Global Initiative for Asthma (GINA) (2019): Global strategy for asthma management and prevention. Based on the Workshop Report, Pp. 199.

6. Global Initiative for Chronic Obstructive Lung Disease (GOLD) (2019): Global strategy for the diagnosis, management, and prevention of chronic obstructive pulmonary disease. Inc, Pp. 139.

7. Guo Y, Hong C, Liu Y Chen H, Huang $X$ and Hong M. (2018): Diagnostic value of fractional exhaled nitric oxide for asthma-chronic obstructive pulmonary disease overlap syndrome. Medicine, 97: 23-27.

8. Han M, Agusti A, Calverley P, Celli BR, Criner G, Curtis JL, Fabbri LM, Goldin JG, Jones PW and Macnee W. (2010): Chronic obstructive pulmonary disease phenotypes: the future of COPD. Am J Respir Crit Care Med., 182: 598-604.

9. Hardin E, Barr R, Hansel N, Hansel NN, Schroeder JD, Make BJ, Crapo JD and Hersh CP. (2011): The clinical features of the overlap between COPD and asthma. Respir Res., 12: 127-132.

10.Harnan S, Gomersall T, Tappenden P, Guida G, Maniscalco M, Motta A and Paoletti G. (2015): A study of exhaled NO (FeNO) measurement used to determine asthma control. J Aller and Clin Immunol., 135: 682-688.

11.Hye Y, Suh Y and Danb C. (2018): Favorable longitudinal changes of lung function in patients with asthma-COPD overlap from a COPD cohort. Respir., 19: 36.

12.Karampitsakos $\mathbf{T}$ and Gourgoulianis $\mathrm{K}$. (2016): ACOS syndrome: Single disease entity or not? Could exhaled nitric oxide be a useful biomarker for the differentiation of ACOS, asthma and COPD? Medical Hypotheses J., 91: 10-16.

13.Kitaguchi Y, Komatsu Y, Fujimoto K, Hanaoka $M$ and Kubo K. (2012): Sputum esinophilia can predict responsiveness to inhaled corticosteroid treatment in patients with overlap syndrome of COPD and asthma. Int $\mathbf{J}$ Chron Obstruct Pulmon Dis., 7: 283-289.

14.Kobayashi $S$, Hanagama $M$ and Yamanda S (2016): Inflammatory biomarkers in asthma-COPD overlap syndrome. Int $\mathrm{J}$ Chron Obstruct Pulmon Dis., 11: 2117-2123.

15.Mostafavi P, Naderi N, Barrecheguren M, Dehghan A and Bourbeau J. (2018): 
Investigating Fractional Exhaled Nitric Oxide in Chronic Obstructive Pulmonary Disease (COPD) and Asthma-COPD Overlap (ACO): A Scoping Review. J COPD., 15: 377-391.

16.Pisi R, Aiello M, Panagiota T, Marangio E, Olivieri D and Chetta A. (2010): Measurement of Fractional Exhaled Nitric Oxide by a New Portable Device: Comparison with the Standard Technique. Asthma J., 77: 174-186.

17.Soler D, Cataluna $M$ and Calle $R$. (2012): Clinical Phenotypes of COPD:
Identification, Definition and Implications for Guidelines. Archivos de bronconeumología, 48: 85-97.

18.Takayama Y, Ohnishi H, Ogasawara F, Oyama K, Kubota T and Yokoyama A. (2018): Clinical utility of fractional exhaled nitric oxide and blood esinophil counts in the diagnosis of asthma-COPD overlap. International Journal of COPD., 13: $525-532$. 
تداخل الربو الثعبي وداء الإنسداد الرئوي المزمن: معايير

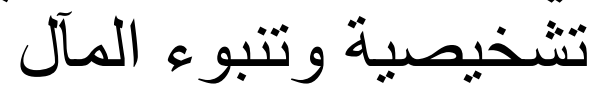

أحمد ابراهيم محمد شتا، موسى عنتر حسـين، عصام محمد غمري، ابراهيم متولي بيومي

قسمي الباطنة العامة والباثولوجيا الإكلينيكية*، كلية الطب، جامعة الأزهر

E-mail: drahmedsheta245@gmail.com

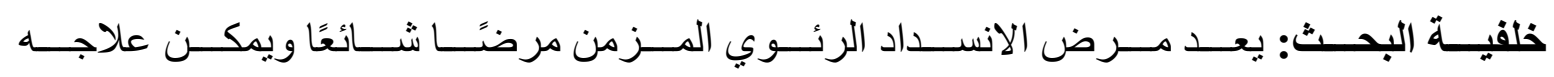

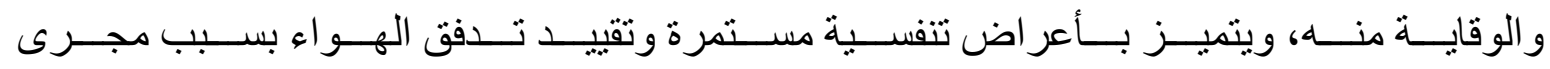

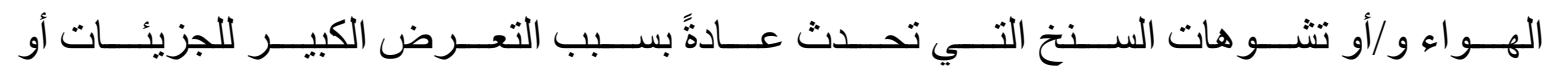

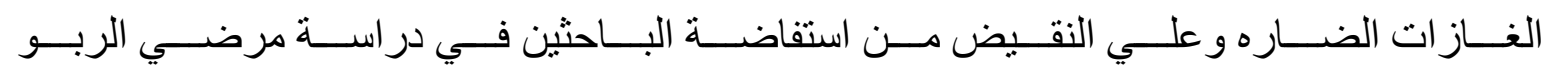

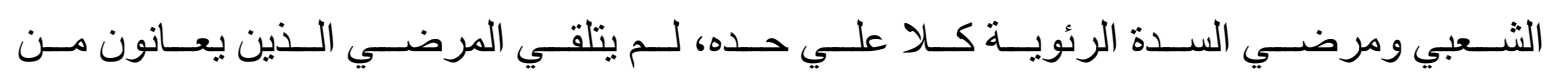

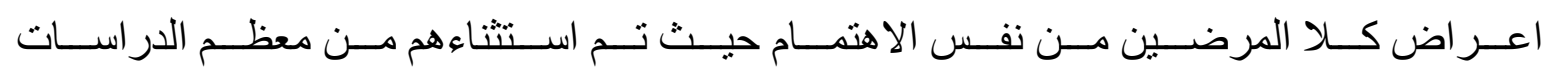

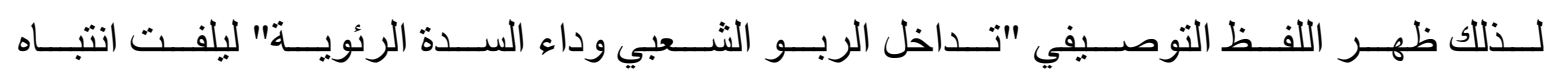

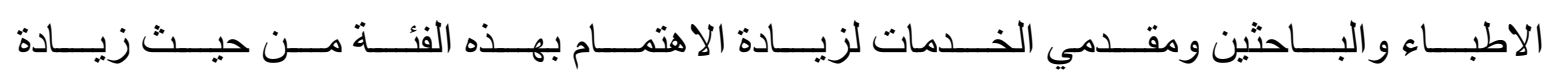

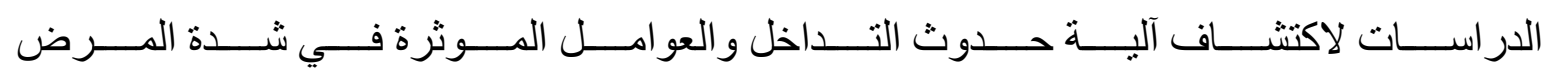
و اكتشاف وسائل تشخيصية و علاجية جديدة.

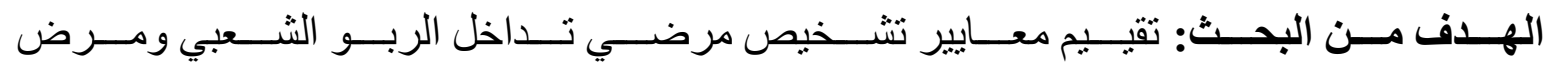

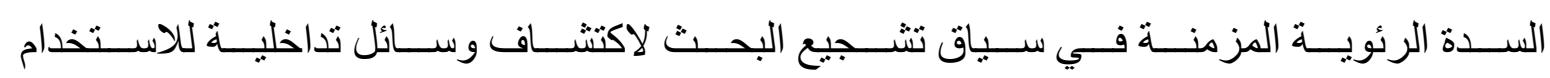
العملي.

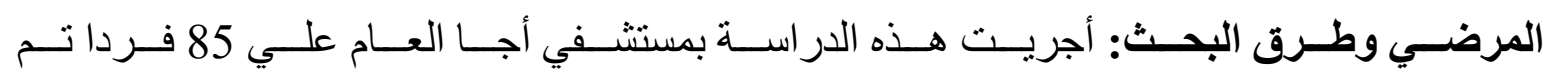

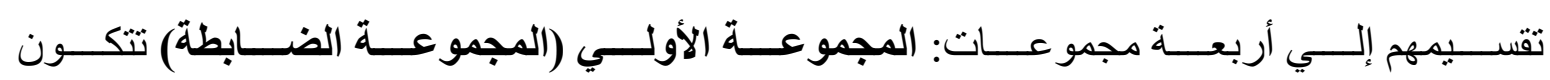

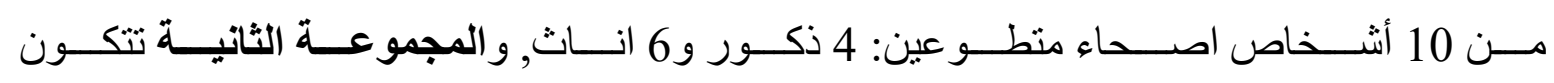

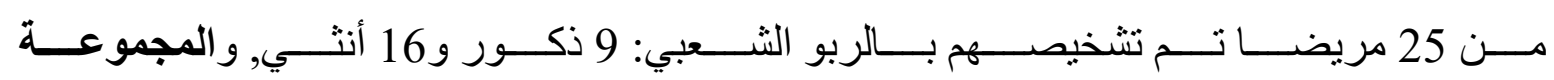

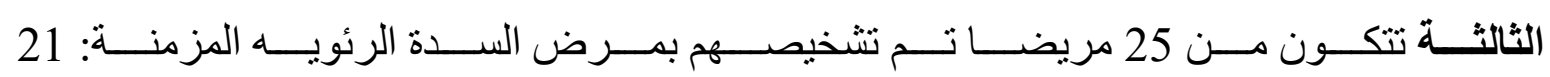

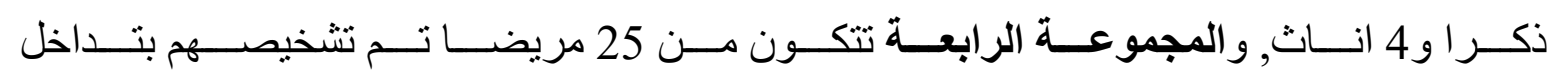

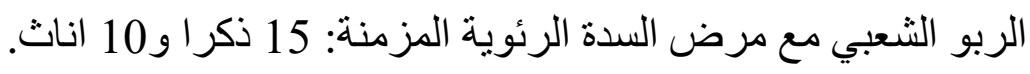


تتــائج البحـــث: أظهــرت نتــائج هــذه الدر اســـة ارتفــاع مســتوي الخلايــــا الحمضــية بالــــم

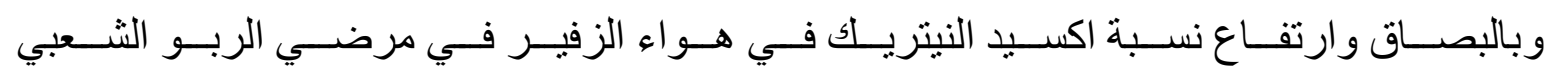

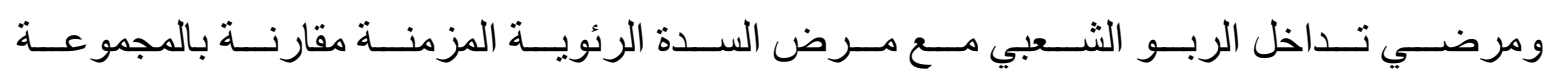

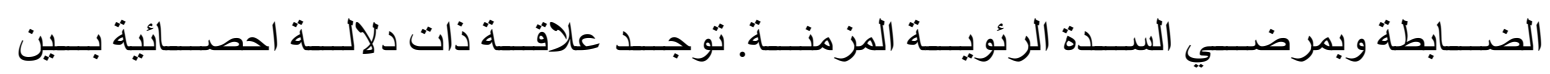

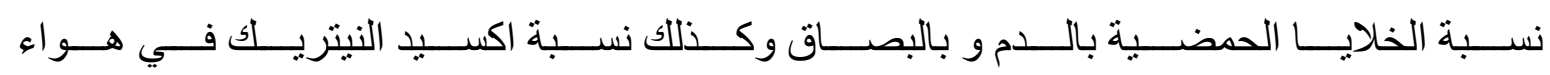

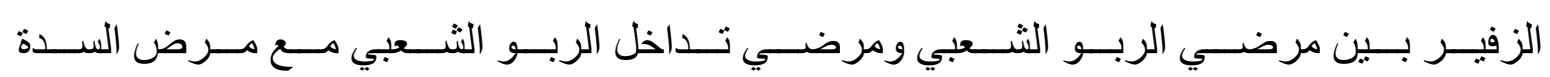

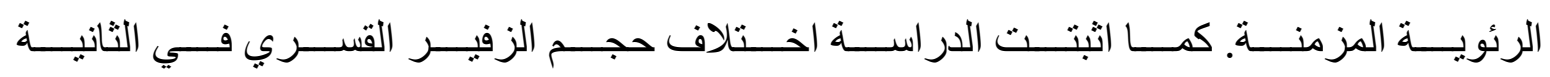

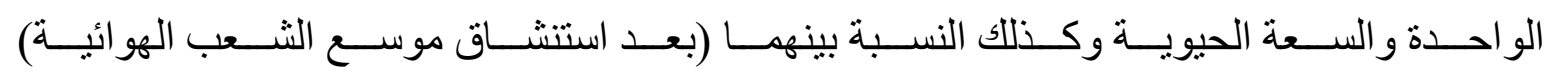

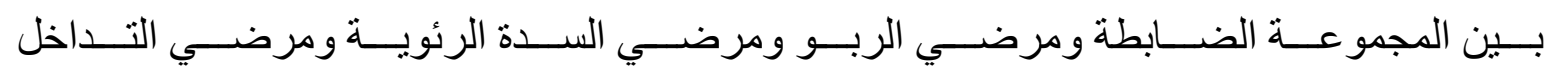
كذلك بين مرضي السدة الرئوية ومرضي التداخل.

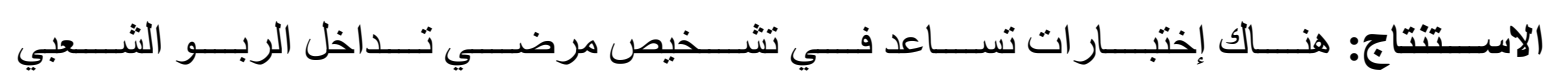

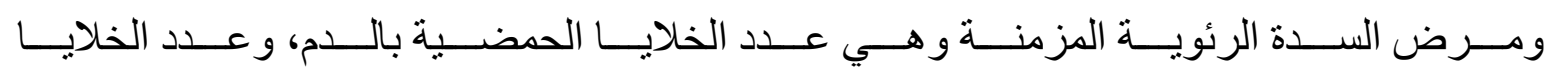

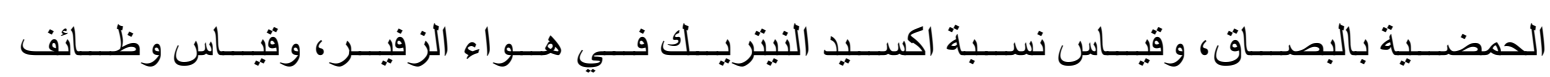
التنفس قبل وبعد استنشاق موسع الثعب الهو ائية.

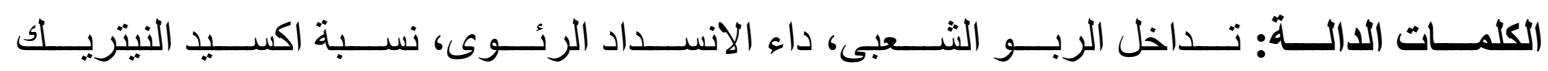
فى هو اء الزفير. 